\title{
Tumor Markers CA 125 and CA 19-9 in Cord Blood and During Infancy: Developmental Changes and Use in Pediatric Germ Cell Tumors
}

\author{
PEKKA LAHDENNE, SARI PITKÄNEN, JUKKA RAJANTIE, PENTTI KUUSELA, \\ MARTTI A. SIIMES, MARJATTA LANNING, AND MARKKU HEIKINHEIMO \\ Children's Hospital [P.L., S.P., J.R., M.A.S., M.H.] and Department of Bacteriology and Immunology \\ [P.K.], University of Helsinki, Finland, Children's Hospital, University of Oulu, Finland [M.L.], and \\ Washington University School of Medicine Children's Hospital, Division of Pediatric \\ Hematology-Oncology, St. Louis, Missouri 63110 [M.H.]
}

\section{ABSTRACT}

\begin{abstract}
Tumor markers CA 125 and CA 19-9 are elevated in a variety of malignancies in adult patients, but only little is known of their biology during gestation or infancy. We have addressed the developmental pattern of these carbohydrate antigens in pediatric patients by measuring their serum levels in 133 cord blood samples from the second through third trimester of gestation and in 39 infants aged less than $1.5 \mathrm{y}$. The serum concentrations of both markers revealed developmental changes, the levels being higher at earlier gestation (wk 24 through 37) than at term or during infancy. The clinical value of the markers was evaluated by monitoring 26 children with germ cell tumors; 14 benign and 2 immature teratomas, and 11 malignant germ cell tumors. Patients with immature sacrococcygeal teratomas showed constant and prolonged elevations of serum CA 125 and CA 19-9. In contrast, all but two children with mature teratomas had normal marker levels; these two patients with abnormally high serum CA 125 and CA 19-9 values for the first 4 postoperative weeks
\end{abstract}

Measurements of oncodevelopmental serum tumor markers AFP and placental proteins such as human chorionic gonadotropin are used in the diagnosis and follow-up of patients with malignant germ cell tumors. AFP synthesis correlates with the presence of yolk sac components within the tumor. Of all patients with malignant germ cell tumors, 36-86\% have elevated serum AFP concentrations (reviewed in Ref. 1). Analogously, tumors containing trophoblastic elements can be identified by the production of human chorionic gonadotropin.

In addition to extra-embryonic elements, various embryonic structures can be found in germ cell tumors. Therefore, antigens derived from embryonic tissues are of potential value as tumor markers in these cases. CA 125 and CA 19-9 are

Received February 3, 1995; accepted May 9, 1995.

Correspondence: Markku Heikinheimo, University of Helsinki, Stenbäckinkatu 11, 00290 Helsinki, Finland.

Supported by the Emil Aaltonen Foundation (S.P.), the Finnish Cultural Foundation (M.H.), and the Finnish Pediatric Foundation (P.L., M.H.). had a benign ovarian and ventricular teratoma, respectively. Of the 11 children with malignant germ cell tumors, serum CA 125 or CA 19-9 concentration was elevated in four patients at diagnosis and declined to normal within 2 wk after institution of therapy. Malignant recurrence in two patients was not associated with a reelevation of the CA 125 level. Taken together, our results demonstrate a developmentally regulated pattern of serum CA 125 and CA 19-9. The carbohydrate markers were usually inferior to $\alpha$-fetoprotein in monitoring of germ cell tumors, but may be a useful adjunct in the follow-up of immature teratomas. (Pediatr Res 38: 797-801, 1995)
AFP, $\alpha$-fetoprotein
Abbreviations
SCT, sacrococcygeal teratoma
95\% CI, age-dependent $95 \%$ confidence interval

carbohydrate antigens originally detected by MAb directed against a colorectal and ovarian epithelial carcinoma cell line, respectively $(2,3)$. The CA 125 and CA 19-9 antigens are found at low concentrations in the sera of healthy adults, but are elevated in patients with ovarian carcinomas and gastrointestinal malignancies (4-9). Only little is known about the role of these markers in childhood malignancies. In children with leukemia and non-germ cell solid tumors, we have reported that the serum levels of CA 125 and CA 19-9 are usually low (10). In another study, CA 19-9 proved not to be a useful tumor marker in 11 adolescents with colorectal carcinoma (11). On the other hand, CA 125 and CA 19-9 are elevated in a subset of children with premalignant and malignant liver diseases (12, 13).

Although CA 125 and CA 19-9 are known to be expressed in fetal tissues (14-16), the ontogenesis of these antigens has not been studied. The serum levels of these markers in infancy have neither been thoroughly explored. The aim of this study 
was to examine the serum levels of CA 125 and CA 19-9 during gestation and infancy. In addition, by taking advantage of our reference values, we illustrate the putative value of these markers in monitoring of children with germ cell tumors.

\section{METHODS}

Cord blood samples. Cord blood samples were collected from the Finnish screening program for congenital hypothyroidism (17). Altogether 105 samples from preterm and 28 samples from term infants were included. In the analysis, the samples from preterm infants were divided into two groups according to the gestational age; samples from those born at 24-32 gestational weeks $(n=32)$ and from those born at 33-37 wk $(n=73)$ (Table 1$)$. The term infants were born at a mean gestational age of $40 \mathrm{wk}$ (range 38-42 wk).

Reference serum samples during infancy. Serum samples from 39 infants waiting for minor surgical operations were obtained at the ages of 0.1 through $1.5 \mathrm{y}$. For the statistical evaluation, the samples were divided into two groups; samples from infants aged $0.1-0.5$ y $(n=22)$ and those from infants aged over 0.5 y $(n=17)$.

Patients with benign teratomas. Sixteen children underwent operation for a benign teratoma between 1985 and 1991 at the Children's Hospital, University of Helsinki, and serial serum samples from these patients were collected for determination of $\operatorname{AFP}(n=79)$, CA $125(n=102)$, and CA 19-9 $(n=112)$. Four to 24 samples (mean 10 samples) from each patient were available. Ten of the children were operated on at their birth day for a neonatal SCT. Of these 10 children with SCT, the teratoma was histologically immature in two. The other patients included three children with an ovarian, one with a testicular, one with a ventricular, and one with an ocular teratoma. At the time of diagnosis these six children were aged $1 \mathrm{~d}$ to $11.4 \mathrm{y}$ (mean $5.0 \mathrm{y}$ ). The postoperative follow-up period was for 0.5-5.2 y (mean $2.0 \mathrm{y}$ ). Besides the tumor, no other organ disorder was found in any of these 16 patients.

Patients with malignant germ cell tumors. Eleven children were treated for a malignant germ cell tumor between 1985 and 1991 at the Children's Hospitals, University of Helsinki and University of Oulu. At the time of diagnosis these children were aged 9 mo to 12 y (mean 2.6 y). After operative and cytostatic treatment the patients were followed up regularly for 2-6 y (mean 3.5 y). From these 11 patients serial serum samples were collected for analyses of AFP $(n=224)$, CA $19-9(n=78)$, and CA $125(n=86)$. Five to 30 samples (mean 17 samples) from each patient were available for this study. In all the children with malignant tumors, a thorough workup for other organ disorders performed at diagnosis and during the follow-up was negative.

Tumor marker analyses. Serum concentrations of CA 125, CA 19-9, and AFP were measured by RIA with the sensitivities of $5.6,6.2$, and $1 \mu \mathrm{g} / \mathrm{L}$, respectively $(1,7,18)$. The reference values for AFP concentrations have been reported using the same laboratory conditions (19). For children older than $18 \mathrm{mo}$, reference values for CA 125 and CA 19-9 reported earlier were used: the upper limits of $95 \%$ confidence interval were 16 and $32 \mathrm{U} / \mathrm{L}$, respectively (10).
Statistical methods. Statistical differences between the groups were analyzed by analysis of variance.

This study was approved by the respective ethical committees.

\section{RESULTS}

CA 125 and CA 19-9 in cord blood. The mean serum concentrations of CA 125 were dependent on the gestational age of the newborn and were 68,34 , and $10 \mathrm{U} / \mathrm{L}$ in cord blood samples from preterm infants born at 24-32 wk, 33-37 wk, and from those born at term, respectively (Fig. 1, Table 1). These differences were also statistically significant (preterm infants born at 24-32 wk versus term infants, $p=0.0001$; preterm infants born at 33-37 wk versus term infants, $p=$ 0.0009: preterm infants born at 24-32 wk versus those born at 33-37 wk, $p=0.01$ ).

In infants born at $24-32 \mathrm{wk}, 33-37 \mathrm{wk}$, and at term, the mean serum concentrations of CA 19-9 were 98, 113, and 53 U/L, respectively (Fig. 2, Table 1). Serum concentrations of CA 19-9 in preterm infants born at wk 33-37 were higher than in term infants $(p=0.04)$, but did not differ between the two preterm groups.

CA 125 and CA $19-9$ in infancy. During infancy, the serum concentrations of CA 125 remained at the low level observed in cord blood of term infants. In contrast, serum concentrations of CA 19-9 continued to decrease postnatally (term infants at birth versus infants aged $0.1-0.5 \mathrm{y}, p=0.0001)$, and reached the level reported earlier for older children (10) by the age of $0.5 \mathrm{y}$.

CA 125, CA 19-9, and AFP in children with benign teratomas. Serum concentrations of CA 125 or CA 19-9 were above the upper limit of age-dependent $95 \% \mathrm{CI}$ in 4 of the 16

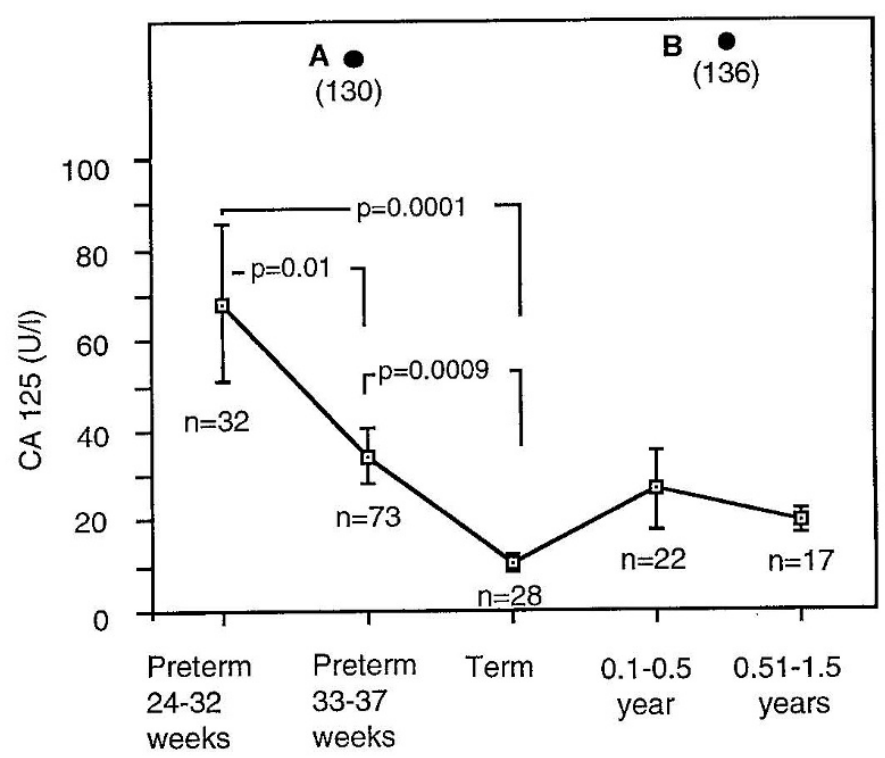

Figure 1. Serum concentrations (mean \pm SEM) of CA 125 in preterm and term infants at birth and in infancy. Number of patients studied is given for each age group under the columns. Closed circles depict serum values at diagnosis of the patient with immature sacrococcygeal teratoma (born at 36 gestational weeks) and the patient with mature ventricular teratoma at the age of $6 \mathrm{mo}$. 
Table 1. Serum concentrations of CA 19-9 and CA 125 (mean and upper limit of 95\% CI) in preterm and term infants at birth and in infants under 1.5 y of age (U/L)

\begin{tabular}{|c|c|c|c|c|c|c|}
\hline \multirow[b]{2}{*}{ Infant group } & \multicolumn{3}{|c|}{ CA 19-9 } & \multicolumn{3}{|c|}{ CA 125} \\
\hline & $n$ & $95 \% \mathrm{Cl}$ & Mean & $n$ & $95 \% \mathrm{CI}$ & Mean \\
\hline \multicolumn{7}{|l|}{ At birth } \\
\hline Preterm (24-32 wk) & 19 & 179 & 98 & 32 & 103 & 68 \\
\hline Preterm (33-37 wk) & 59 & 150 & 113 & 73 & 47 & 34 \\
\hline Term $(38-42$ wk) & 28 & 70 & 53 & 28 & 14 & 10 \\
\hline \multicolumn{7}{|l|}{ Postnatal } \\
\hline $0.1-0.5$ y & 22 & 42 & 30 & 22 & 45 & 25 \\
\hline $0.51-1.5 \mathrm{y}$ & 17 & 24 & 19 & 17 & 25 & 20 \\
\hline
\end{tabular}

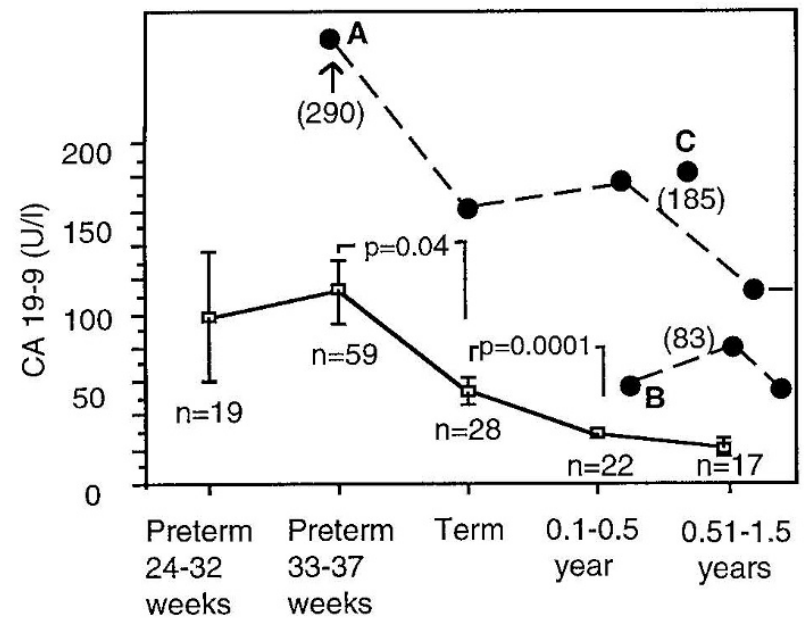

Figure 2. Serum concentrations (mean \pm SEM) of CA 19-9 in preterm and term infants at birth and in infancy. Number of patients studied is given for each age group under the columns. Closed circles connected with dotted lines depict serial serum values of the two patients with immature sacrococcygeal teratomas born at 36 gestational weeks $(A)$ and born at term $(B)$, and serum CA 19-9 at diagnosis of a patient with mature ventricular teratoma at the age of 6 mo.

children with benign teratomas; two immature SCT, one ventricular teratoma, and one ovarian teratoma (Table 2, Figs. 1 and 2). The two patients with an immature teratoma showed prolonged elevations of these markers, although in one of them CA 19-9 and CA 125 at birth levels had been within the reference range.

In all 16 patients with benign teratomas, serum concentrations of AFP remained within the age-dependent reference values throughout the follow-up period. Based on elevations in the AFP levels, malignant recurrences were suspected in the two patients operated on for immature SCT; no recurrences were, however, found in these two or in any of the other patients.

CA 125, CA 19-9 and AFP in children with malignant germ cell tumors. Four of the 11 patients with malignant germ cell tumors showed elevated serum concentrations of CA 125 or CA 19-9 during follow-up (Table 2). In 10 patients, serum AFP was elevated, ranging from 430 to $179,000 \mu \mathrm{g} / \mathrm{L}$ (mean $40,760 \mu \mathrm{g} / \mathrm{L}$ ) at diagnosis. In a 2 -y-old boy with a sacrococcygeal yolk sac tumor and elevated serum APF and CA 125 level at diagnosis, a malignant recurrence was associated with elevated AFP, but normal CA 125 levels. A 2-y-old boy operated on for a testicular embryonal carcinoma had serum
CA 125 levels fluctuating at two to four times the upper $95 \%$ $\mathrm{Cl}$ for 3 months postoperatively; the patient remained diseasefree during the follow-up. Serum CA 19-9 was elevated (2.9 times $95 \% \mathrm{CI}$ ) at diagnosis in one patient with an ovarian embryonal carcinoma, and CA 125 (4.8 times 95\% Cl) in another patient; malignant recurrence in the latter patient was not associated with an elevation of any of the markers studied.

\section{DISCUSSION}

CA 125 and CA 19-9 are expressed in fetal tissues (14-16), but serum concentrations of these antigens at various gestational ages or during infancy have not been studied earlier. During fetal development the CA 125 antigen is localized to the amnion, derivatives of Müllerian epithelium, e.g. endometrium, endocervix, and Fallopian tube and coelomic epithelium, including the peritoneum, pleura and pericardium (14, 16). Expression of the antigen on these developmental sites is maintained through adulthood, resulting in the presence of low serum levels of CA 125 in all non-tumor-bearing adults (20). Elevated levels of CA 125 are found in patients with diseases, benign or malignant, affecting these tissues (8). High serum CA 125 levels in pregnant women $(7,21)$ and abundant levels of CA 125 in amniotic fluid (22) further demonstrate that CA 125 antigen is expressed during normal growth and development. It can be speculated that the high serum levels of CA 125 during gestation observed in the present study may be caused by the rapid fetal growth of tissues and organs. On the other hand, because circulating glycoproteins are largely cleared by the liver (23), immaturity of hepatic function in preterm infants may also increase the serum levels of CA 125. Impairment of the liver function or malignant changes in the liver is also associated with elevated serum CA 125 in a subset of patients with hereditary tyrosinemia and hepatoblastomas $(12,13)$. CA 19-9 is not as widely distributed as CA 125 during fetal life. Raux et al (15) detected this antigen in the fetal gastrointestinal tract but not in other fetal organs. The CA 19-9 antigen has been detected only in trace amounts in normal adult digestive organs (15), but the tissue expression and serum concentrations of this antigen are increased in malignant gastrointestinal diseases $(9,24)$. For this reason, CA $19-9$ has been viewed as an oncofetal antigen for gastrointestinal tract, although it is obviously not organ- or tumor-specific $(25,26)$. Our findings of elevated but declining serum levels of CA 19-9 toward the end of gestation support the concept of oncofetal character of this antigen. 
Table 2. Children treated for benign or malignant germ cell tumors with elevated serum levels of CA 19-9 and/or CA 125 (the upper limit of age-dependent 95\% CI of serum CA 19-9 and CA 125 is given in parentheses under each serum value)

\begin{tabular}{|c|c|c|c|c|c|c|c|}
\hline \multirow[b]{2}{*}{$\begin{array}{l}\text { Patient age at } \\
\text { diagnosis }\end{array}$} & \multirow[b]{2}{*}{$\begin{array}{l}\text { Histologic } \\
\text { diagnosis }\end{array}$} & \multirow[b]{2}{*}{ Location } & \multicolumn{4}{|c|}{ At diagnosis } & \multirow[b]{2}{*}{ Remarks } \\
\hline & & & $\begin{array}{l}\mathrm{CA} \\
(\mathrm{U}\end{array}$ & $\begin{array}{l}19-9 \\
J / L)\end{array}$ & $\begin{array}{l}\text { CA } 125 \\
(\mathrm{U} / \mathrm{L})\end{array}$ & $\begin{array}{c}\text { AFP } \\
(\mu g / L)\end{array}$ & \\
\hline \multicolumn{8}{|l|}{ Benign tumors } \\
\hline $\begin{array}{l}1 \mathrm{~d} \text { (born at } 36 \\
\text { gest wk) }\end{array}$ & $\begin{array}{l}\text { Immature } \\
\text { teratoma }\end{array}$ & Sacrococcyx & 290 & $(150)$ & $130(47)$ & 51270 & $\begin{array}{l}\text { CA 19-9 80-170 U/L for } 3 \text { y. CA } \\
125 \text { normal } 1 \text { wk postoperatively }\end{array}$ \\
\hline $1 \mathrm{~d}$ & $\begin{array}{l}\text { Immature } \\
\text { teratoma }\end{array}$ & Sacrococcyx & 26 & $(70)$ & $33(14)$ & 40665 & $\begin{array}{c}\text { CA } 19-955-83 \mathrm{U} / \mathrm{L}, \mathrm{CA} 12525-47 \\
\mathrm{U} / \mathrm{L} \text { between } 6 \text { and } 15 \text { mo of age }\end{array}$ \\
\hline $6 \mathrm{mo}$ & $\begin{array}{l}\text { Mature } \\
\text { teratoma }\end{array}$ & Ventricle & 185 & $(42)$ & $136(25)$ & 58 & $\begin{array}{l}\text { CA } 19-9 \text { and CA } 125 \text { normal } 4 \text { wk } \\
\text { postoperatively }\end{array}$ \\
\hline $11 \mathrm{y}$ & $\begin{array}{l}\text { Mature } \\
\text { teratoma }\end{array}$ & Ovary & 270 & $(32)$ & $84(16)$ & 2.5 & $\begin{array}{l}\text { CA } 19-9 \text { and CA } 125 \text { normal } 4 \text { wk } \\
\text { postoperatively }\end{array}$ \\
\hline \multicolumn{8}{|l|}{ Malignant tumors } \\
\hline $2 y$ & $\begin{array}{l}\text { Yolk sac } \\
\text { tumor }\end{array}$ & Sacrococcyx & 27 & $(32)$ & $71(16)$ & 179000 & $\begin{array}{l}\text { CA } 125 \text { normal in } 2 \text { wk } \\
\text { postoperatively. Malignant } \\
\text { recurrence } 8 \text { mo later: AFP } 118 \\
\mu \mathrm{g} / \mathrm{L}, \text { CA } 19-9 \text { and CA } 125 \\
\text { normal }\end{array}$ \\
\hline $2 \mathrm{y}, 3 \mathrm{mo}$ & $\begin{array}{l}\text { Embryonal } \\
\text { carcinoma }\end{array}$ & Testicle & 10 & (32) & $38(16)$ & 521 & $\begin{array}{l}\text { CA } 12532-70 \mathrm{U} / \mathrm{L} 3 \mathrm{mo} \\
\text { postoperatively }\end{array}$ \\
\hline $2 \mathrm{y}, 6 \mathrm{mo}$ & $\begin{array}{l}\text { Embryonal } \\
\text { carcinoma }\end{array}$ & Ovary & $<6.2$ & $(32)$ & $77(16)$ & $<9$ & $\begin{array}{l}\text { CA } 125 \text { normal in } 2 \text { wk } \\
\text { postoperatively. Malignant } \\
\text { recurrence } 1 \text { y later: CA } 125, \text { CA } \\
19-9 \text {, and AFP low }\end{array}$ \\
\hline $12 y$ & $\begin{array}{l}\text { Embryonal } \\
\text { carcinoma }\end{array}$ & Ovary & 93 & $(32)$ & Not done & 25500 & $\begin{array}{l}\mathrm{hCG} 49000 \mathrm{IU} / \mathrm{L} \text { at diagnosis, CA } \\
19-9 \text { normal in } 2 \mathrm{wk} \\
\text { postoperatively }\end{array}$ \\
\hline
\end{tabular}

The reference values during late gestation and infancy, demonstrated in this work, form the basis for the potential use of CA 19-9 and CA 125 in the diagnosis and follow-up of patients with neonatal neoplasia. These markers may be elevated in children with some embryonal tumors such as hepatoblastomas (13) as well as in hereditary tyrosinemia, a premalignant liver disease (12). Serum CA 125 was also found to be elevated in children with abdominal Burkitt's lymphomas (10). CA 19-9 and CA 125 may thus have a role in the follow-up of patients with specific childhood malignancies. SCT are of special interest, because these tumors may give rise to malignant recurrences even when originally benign $(27,28)$. In the present patients with mature SCT, CA 125 and CA 19-9 were exclusively within reference limits in infancy. In contrast, the patients with immature teratomas showed prolonged elevations of both markers studied. No malignant recurrences, however, were noted in these children. Therefore, it cannot be answered whether CA 125 and CA 19-9 would be useful in predicting early malignant recurrences of immature teratomas. Four patients with malignant germ cell tumors showed elevated levels of CA $19-9$ or CA 125 at diagnosis. Malignant recurrences in two of these did not elevate the serum levels of either antigen. Thus, the enhanced expression of CA 125 and CA 19-9 in patients with immature teratomas may rather reflect immaturity than malignant behavior of the tumors. No other organ abnormalities than the tumor were detected in our patients; thus elevated values were not due to any other medical condition described to be associated with elevated serum carbohydrate antigens $(14,16)$.

Developmental changes in serum levels of tumor markers CA 125 and CA 19-9 were observed during late gestation and infancy adding to the evidence for their oncofetal character. These markers did not prove useful as diagnostic markers for all children with germ cell tumors, but may be of value in the follow-up of patients with elevated serum levels at diagnosis. In comparison with AFP, the classic tumor marker of germ cell malignancies, CA 125 and CA 19-9 proved to be inferior. These markers were, however, elevated in immature teratomas, and determination of CA 125 and CA 19-9 may give additional information during the follow-up of these children.

\section{REFERENCES}

1. Ruoslahti E, Seppälä M $1979 \alpha$-Fetoprotein in cancer and fetal development. Adv Cancer Res 29:275-346

2. Koprowski H, Steplewski Z, Mitchell K, Herlyn M, Herlyn D, Fuhrer P 1979 Colorectal carcinoma antigens detected by hybridoma antibodies. Somat Cell Genet 5:957-972

3. Bast RC, Klug TL, St John E, Jenison E, Niloff JM, Lazarus H, Berkowitz RS, Leavitt T, Griffiths CT, Parker L, Zurawski VR, Knapp RC 1983 A radioimmunoassay using monoclonal antibody to monitor the course of epithelial ovarian cancer. N Engl J Med 309:883-887

4. Herlyn M, Sears HF, Steplewski Z, Koprowski H 1982 Monoclonal antibody detection of a circulating tumor-associated antigen. I. Presence of antigen in sera of patients with colorectal, gastric, and pancreatic carcinoma. J Clin Immunol 2:135-140

5. Jalanko H, Kuusela P, Roberts P, Sipponen P, Haglund C, Mäkelä O 1984 Comparision of new tumour marker, CA 19-9, with $\alpha$-fetoprotein and carcinoembryonic antigen in patients with upper gastrointestinal diseases. J Clin Pathol 37:218-222

6. Kuusela $P$, Jalanko H, Roberts $P$, Sipponen $P$, Mecklin JP, Pitkänen R, Mäkelä $O$ 1984 Comparision of CA 19-9 and carcinoembryonic antigen (CEA) levels in the serum of patients with colorectal diseases. Br J Cancer 49:135-139

7. Halila H, Stenman U-H, Seppälä M 1986 Ovarian cancer antigen CA 125 levels in pelvic inflammatory disease and pregnancy. Cancer 57:1327-1329

8. Daoud E, Bodor G 1991 CA-125 concentrations in malignant and nonmalignant disease. Clin Chem 37:1968-1974

9. Haglund C, Roberts CJ, Jalanko H, Kuusela H 1992 Tumour markers CA 19-9 and CA 50 in digestive tract malignancies. Scand J Gastroenterol 27:169-174 
10. Heikinheimo M, Rajantie J, Kuusela P, Kallio MJT, Siimes MA 1990 Oncofetal markers CA 19-9, CA 125 and SP1 in healthy children and in children with leukemia and solid tumors. Br J Cancer 62:865-867

11. Angel CA, Pratt CB, Rao BN, Schell MJ, Parham DM, Lobe TE, Fleming ID 1992 Carcinoembryonic antigen and carbohydrate 19-9 antigen as markers for colorectal carcinoma in children and adolescents. Cancer 69:1487-1491

12. Pitkänen S, Salo MK, Kuusela P, Holmberg C, Simell O, Heikinheimo M 1994 Serum levels of oncofetal markers CA 125, CA $19-9$ and $\alpha$-fetoprotein in children with hereditary tyrosinemia type I. Pediatr Res 25:205-208

13. Heikinheimo M, Pitkänen S, Kuusela P, Mäkipernaa A, Rapola J, Mellander L, Riikonen P, Perkkiö M 1995 Serum levels of oncofetal markers CA 19-9 and CA 125 in children with hepatoblastoma. Int J Ped Hem Oncol 1:599-603

14. Kabawat SE, Bast RC, Bhan AK, Welch WR, Knapp RC, Colvin RB 1983 Tissue distribution of a coelomic-epithelium-related antigen recognized by the monoclonal antibody OC 125. Int J Gynecol Pathol 2:275-285

15. Raux H, Labbe F, Fondaneche C-M, Koprowski H, Burtin P 1983 A study of gastrointestinal cancer-associated antigen (GICA) in human fetal organs. Int J Cancer 32:315-319

16. Hardardottir H, Parmley TH, Quirk JG, Sanders MM, Miller FC, O'Brien TJ 1990 Distribution of CA 125 in embryonic tissues and adult derivatives of fetal periderm. Am J Obstet Gynecol 163:1925-1931

17. Virtanen M, Perheentupa J, Mäenpää J, Pitkänen L, Pikkarainen J 1984 Finnish national screening for hypothyroidism. Few false positives, early therapy. Eur $\mathrm{J}$ Pediatr 143:2-5

18. Haglund C, Roberts PJ, Kuusela P, Scheinin TM, Mäkelä O, Jalanko H 1986 Evaluation of CA 19-9 as a serum tumour marker in pancreatic cancer. Br J Cancer 53:197-202
19. Lahdenne P, Kuusela P, Siimes MA, Rönnholm KAR, Salmenperä L, Heikinheimo M 1991 Biphasic reduction and concanavalin A binding properties of serum [alpha]fetoprotein in preterm and term infants. J Pediatr 118:272-276

20. O'Brien TJ, Raymond LM, Bannon GA, Ford DH, Hardardottir H, Miller FC, Quirk JG 1991 New monoclonal antibodies identify the glycoprotein carrying the CA 125 epitope. Am J Obstet Gynecol 165:1857-1864

21. Seki K, Kikuchi Y, Uesato T, Kato K 1986 Increased serum CA 125 levels during the first trimester of pregnancy. Acta Obstet Gynecol Scand 65:583-585

22. O'Brien TJ, Hardin JW, Bannon GA, Norris JN, Quirk JG 1986 CA 125 antigen in human amniotic fluid and fetal membranes. Am J Obstet Gynecol 155:50-55

23. Ashwell G, Harford J 1982 Carbohydrate-specific receptors of the liver. Annu Rev Biochem 51:531-554

24. Nishida K, Miyagawa H, Yoshikawa T, Kondo M 1988 Concentration and localization of carbohydrate antigen 19-9 in tissues of pancreatic cancer. Oncology 45:166171

25. Koprowski H, Herlyn M, Steplewski Z 1981 Specific antigen in serum of patients with colon carcinoma. Science 212:53-54

26. von Kleist S 1986 The clinical value of tumor markers CA 19-9 and carcinoembryonic antigen (CEA) in colorectal carcinomas: a critical comparison. Int J Biol Markers $1: 3-8$

27. Berry CL, Keeling J, Hilton C 1969 Teratomata in infancy and childhood: a review of 91 cases. J Pathol 98:241-252

28. Gonzalez-Crussi F, Winkler RF, Mirkin DL 1978 Sacrococcygeal teratomas in infants and children. Relationship of histology and prognosis in 40 cases. Arch Pathol Lab Med 102:420-425 